\title{
AGES AND SOURCES OF DETRITAL ZIRCONS FROM THE EARLY MESOZOIC METASEDIMENTARY ROCKS OF THE UN'YA-BOM TERRANE OF THE MONGOL-OKHOTSK FOLD BELT: RESULTS OF U-TH-PB AND LU-HF ISOTOPE STUDIES
}

\author{
V. A. Zaika, A. A. Sorokin \\ Institute of Geology and Nature Management, Far East Branch of RAS, Blagoveshchensk, Russia
}

\begin{abstract}
The U-Pb and Lu-Hf isotope studies have been performed to investigate detrital zircons from metaterrigenous deposits (Nel, Kurnal and Amkan formations) of the Un'ya-Bom terrane of the eastern part of the MongolOkhotsk fold belt. The concordant ages of the youngest zircon in the metasiltstone of the studied formations are as follows: $213 \pm 3.6 \mathrm{Ma}-\mathrm{Nel}, 194 \pm 4.4 \mathrm{Ma}-$ Kurnal, and 202 $\pm 2.5 \mathrm{Ma}-$ Amkan. The new data suggest that a previously assumed (Middle Jurassic) age of the Amkan formation is uncertain. Most likely, the Kurnal and Amkan formations are of the same (Early Jurassic) age. In any case, a relationship between these formations needs to be clarified. In combination with the data from previous studies of the Tukuringra terrane, our study results show that the Early Mesozoic sedimentary rocks in the structure of the eastern part of the Mongol-Okhotsk fold belt are more abundant than it is currently assumed. Our study results suggest that during the accumulation of the Nel, Kurnal and Amkan formations, the materials were supplied from different provinces, especially from the Amur superterrane (i.e. from the south, in modern coordinates), as well as from the frame of the North Asian craton (i.e from the north, in modern coordinates), although the contribution of the craton source was insignificant.
\end{abstract}

Key words: Mongol-Okhotsk fold belt; Un'ya-Bom terrane; U-Th-Pb and Lu-Hf isotopic studies; metasedimentary rocks; detrital zircons

For citation: Zaika V.A., Sorokin A.A., 2019. Ages and sources of detrital zircons from the Early Mesozoic metasedimentary rocks of the Un'ya-Bom terrane of the Mongol-Okhotsk fold belt: results of U-Th-Pb and Lu-Hf isotope studies. Geodynamics \& Tectonophysics 10 (3), 801-813. doi:10.5800/GT-2019-10-3-0442. 


\title{
ВОЗРАСТ И ИСТОЧНИКИ ОБЛОМОЧНЫХ ЦИРКОНОВ ИЗ РАННЕМЕЗОЗОЙСКИХ МЕТАОСАДОЧНЫХ ПОРОД УНЬЯ-БОМСКОГО ТЕРРЕЙНА МОНГОЛО-ОХОТСКОГО СКЛАДЧАТОГО ПОЯСА: РЕЗУЛЬТАТЫ U-TH-РВ И LU-НF ИЗОТОПНЫХ ИССЛЕДОВАНИЙ
}

\author{
В. А. Заика, А. А. Сорокин \\ Институт геологии и природопользования ДВО РАН, Благовещенск, Россия
}

\begin{abstract}
Аннотация: В данном сообщении представлены результаты U-Pb и Lu-Hf изотопных исследований детритовых цирконов из метатерригенных отложений (нелская, курнальская, амканская свита) Унья-Бомского террейна восточной части Монголо-Охотского складчатого пояса. Установлено, что конкордантный возраст наиболее молодого циркона в метаалевролите нелской свиты составляет $213 \pm 3.6$ млн лет, метаалевролите

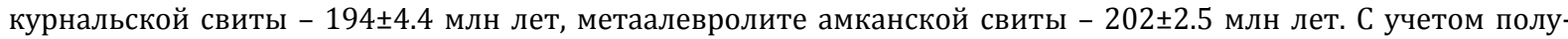
ченных данных, предполагаемый ранее среднеюрский возраст амканской свиты становится сомнительным. Скорее всего, курнальская и амканская свиты имеют один и тот же (раннеюрский) возраст. В любом случае взаимоотношение этих свит требует уточнения. Эти данные в совокупности с ранее проведенными исследованиями Тукурингрского террейна указывают на то, что раннемезозойские осадочные комплексы в строении восточной части Монголо-Охотского пояса развиты существенно шире, чем принято считать в настоящее время. На основе полученных данных показано, что поступление материала в период накопления нелской, курнальской и амканской свит происходило из разных провинций, а именно со стороны Амурского супертеррейна (с юга в современных координатах) и со стороны обрамления Северо-Азиатского кратона (с севера в современных координатах), однако вклад последнего источника был незначительным.
\end{abstract}

Ключевые слова: Монголо-Охотский складчатый пояс; Унья-Бомский террейн; U-Th-Pb и Lu-Hf изотопные исследования; метаосадочные породы; детритовые цирконы

\section{1. ВВЕДЕНИЕ}

Монголо-Охотский складчатый пояс является одним из значимых структурных элементов Восточной Азии. В настоящее время этот пояс обычно рассматривается в качестве реликта одноименного палеоокеана (см. обзор в [Parfenov et al., 2001; Khanchuk et al., 2015]), фрагменты которого зажаты между Северо-Азиатским кратоном на севере и Амурским супертеррейном на юге.

Геодинамические модели формирования Монголо-Охотского складчатого пояса, существующие в настоящее время, имеют во многом противоречивый характер (см. обзор в [Natal'in, 1993; Parfenov et al., 2001; Khanchuk et al., 2015]). В первую очередь это обусловлено недостатком геохронологических и изотопно-геохимических данных.

Одним из путей решения этой проблемы являются исследования структурно-разновозрастных магматических и осадочных комплексов. Получаемые результаты позволяют определить граничные условия для разработки таких моделей.

В этой связи мы выполнили U-Th-Pb геохронологические и Lu-Hf изотопные исследования дет- ритовых цирконов метаосадочных пород УньяБомского террейна Монголо-Охотского складчатого пояса с целью установления их источников и областей сноса обломочного материала. Данная работа является логическим продолжением исследований восточной части Монголо-Охотского пояса [Zaika et al., 2018a, 20181b, 2019], направленных на реконструкцию истории его формирования.

\section{2. АНАЛИТИЧЕСКИЕ МЕТОДИКИ}

Выделение цирконов из образцов выполнено в минералогической лаборатории ИГиП ДВО РАН с применением тяжелых жидкостей. Далее цирконы совместно со стандартными цирконами (FC, SL и R33) были вмонтированы в шашку, изготовленную из эпоксидной смолы, и приполированы приблизительно до середины зерен. Внутреннее строение зерен циркона исследовалось в режиме BSE и CL c использованием сканирующего электронного микроскопа Hitachi S-3400N, оснащенного детектором Gatan Chroma CL2. U-Th-Pb геохронологические исследования цирконов выполнены в Геохронологи- 
ческом центре Аризонского университета (Arizona LaserChron Center, USA) с использованием системы лазерной абляции Photon Machines Analyte G2 и ICP масс-спектрометра Thermo Element 2. Диаметр кратера составлял 20 мкм, глубина - 15 мкм. Калибровка проводилась по стандарту FC (Duluth complex, 1099.3 \pm 0.3 млн лет [Paces, Miller, 1993]). В качестве вторичных стандартов для контроля измерений использовались цирконы SL (Sri Lanka) и R33 (Braintree complex) [Black et al., 2004]. Значения

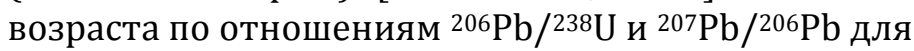
стандарта SL в процессе измерений составили

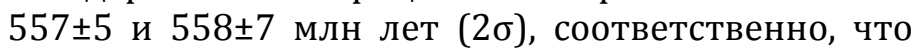
хорошо согласуется со значениями, опубликованными в работе [Gehrels et al., 2008], полученными с использованием ID-TIMS метода. Средние значения возраста по отношениям $206 \mathrm{~Pb} /{ }^{238} \mathrm{U}$ and ${ }^{207} \mathrm{~Pb} / 206 \mathrm{~Pb}$

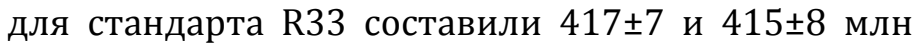
лет, что соответствует рекомендованным [Black et al., 2004; Mattinson, 2010]. Систематические погрешности составляют $0.9 \%$ для отношения ${ }^{206} \mathrm{~Pb} /{ }^{238} \mathrm{U}$ и $0.8 \%$ для отношения ${ }^{206} \mathrm{~Pb} /{ }^{207} \mathrm{~Pb}(2 \sigma)$. Поправки на обычный $\mathrm{Pb}$ вводились по ${ }^{204} \mathrm{~Pb}$, скорректированному на ${ }^{204} \mathrm{Hg}$, в соответствии с модельными величинами [Stacey, Kramers, 1975]. Детальное описание аналитических процедур приведено на сайте лаборатории (www.laserchron.org). Конкордантные возрасты (Concordia Ages) рассчитаны в программе Isoplot (version 3.6) [Ludwig, 2008].

Lu-Hf изотопные анализы цирконов были выполнены в Геохронологическом центре Аризонского университета (Arizona LaserChron Center, USA) с использованием многоколлекторного масс-спектрометра с индукционно-связанной плазмой (MC-ICPMS) Nu High-Resolution и эксимерного лазера Analyte G2. Для настройки и проверки качества анализов использовались стандартные растворы JMC475, Spex Hf и Spex Hf, Yb и Lu, а также стандартные цирконы Mud Tank, 91500, Temora, R33, FC52, Plesovice и SL. Hf изотопные анализы проводились в том же месте цирконов, что и U-Th-Pb анализы. Диаметр лазерного пучка составлял 40 мкм, мощность лазера около 5 Дж/см², частота 7 Гц, скорость абляции около 0.8 мкм/с. Детали аналитической методики изложены на сайте http://www.laserchron.org. Для расчета величин $\varepsilon_{\mathrm{Hf}(\mathrm{t})}$ использованы константа распада ${ }_{176} \mathrm{Lu}\left(\lambda=1.867 \mathrm{e}^{-11}\right)$ по [Söderlund et al., 2004], хондритовые отношения ${ }^{176} \mathrm{Hf} /{ }^{177} \mathrm{Hf}(0.282785)$ и ${ }^{176} \mathrm{Lu} /{ }^{177} \mathrm{Hf}$ (0.0336) по [Blichert-Toft, Albarède, 1997]. Коровые Hf модельные возрасты $t_{\text {нf(c) }}$ рассчитаны с учетом среднего отношения ${ }^{176} \mathrm{Lu} /{ }^{177} \mathrm{Hf}$ в континентальной коре, равного 0.0093 [Vervoort, Patchett, 1996; Amelin et al., 1999]. Для расчета изотопных параметров деплетированной мантии использованы современные отношения ${ }^{176} \mathrm{Hf} /{ }^{177} \mathrm{Hf}=0.28325$ и ${ }^{176} \mathrm{Lu} /{ }^{177} \mathrm{Hf}=0.0384$ [Griffin et al., 2004].

\section{3. ОБЪЕКТЫ ИССЛЕДОВАНИЙ}

Как было отмечено выше, объектами наших исследований являются метаосадочные породы Унья-Бомского террейна Монголо-Охотского складчатого пояса. Этот террейн вытянут в субширотном направлении почти на 180 км при максимальной ширине 15-20 км (рис. 1, 2). Северная граница террейна перекрыта кайнозойскими отложениями Верхнезейской впадины, на северо-востоке по зонам Огодженонского и Ланского разломов граничит с Ланским террейном, по зоне Джелтулинского разлома с юго-запада - с Джагдинским террейном.

В его строении (снизу вверх) выделяют последовательность стратифицированных образований [Serezhnikov, Volkova, 2007].

1. Условно верхнетриасовая муяканская свита, мощностью 1200 м, представлена метапесчаниками с прослоями и линзами филлитов, метаалевролитов, зеленых сланцев, туфопесчаников, седиментационных брекчий, туффитов.

2. Верхнетриасовая нелская свита, мощностью 1200 м, представлена филлитами, метаалевролитами и метапесчаниками, часто флишоидно переслаивающимися, реже зелеными и кремнистыми сланцами, седиментационными брекчиями. Нелская свита содержит фауну, характерную для карнийского и низов норийского яруса верхнего триаca: MonotisochoticaKeys., M. jacuticaTell., EomonotisscutiformisKipar., Halobiacf. australicaMoys., Oxytoma (Palmoxytoma) moysisovicsi Tell.

3. Нижнеюрская курнальская свита, мощностью 2000 м, сложена разнозернистыми полимиктовыми рассланцованными песчаниками, иногда туфогенными. Филлитизированные алевролиты, гравелиты, седиментационные брекчии и конгломераты слагают маломощные прослои. Возраст курнальской свиты определен по находкам криноидей Seirocrinusalaska(Spring.), Seirocrinuscf. subangularis (Mill.) ранней юры.

4. Условно среднеюрская амканская свита, мощностью до 1500 м, сложена ритмично переслаивающимися песчаниками, алевролитами и аргиллитами. Мощные пачки этих пород перемежаются с пластами разнозернистых песчаников и филлитизированных алевролитов, реже глинистых сланцев. Конгломераты образуют редкие маломощные прослои. Среднеюрский возраст свиты предполагается на основании ее согласного налегания на раннеюрскую курнальскую свиту. Органических остатков свита не содержит.

Породы указанных стратиграфических подразделений неравномерно метаморфизованы в условиях зеленосланцевой фации [Serezhnikov, Volkova, 2007]. 


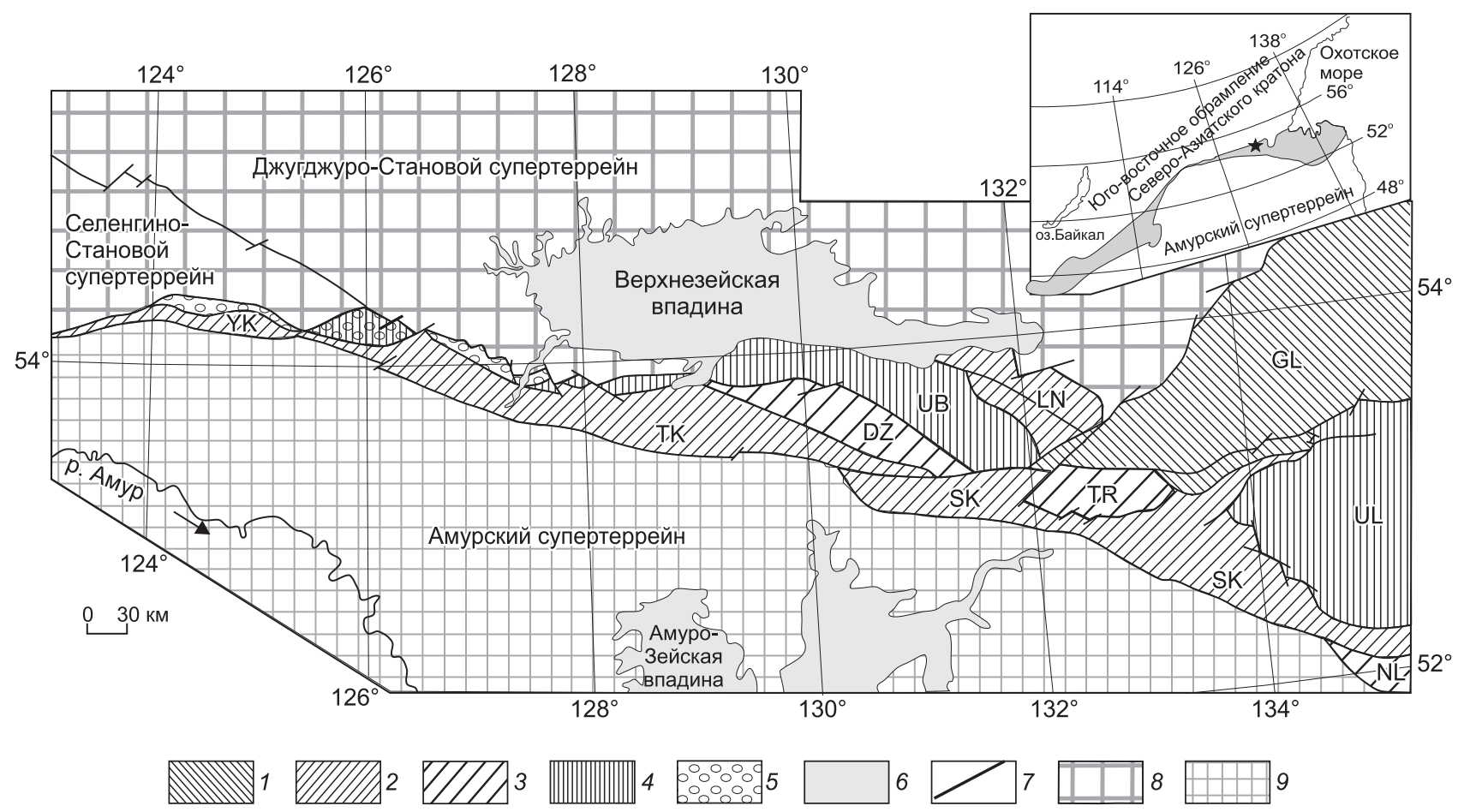

Рис. 1. Схема структурного районирования восточной части Монголо-Охотского складчатого пояса (по [Sorokin, 2001]).

1 - террейны, сложенные преимущественно ранне- и среднепалеозойскими метаосадочными и метавулканическими комплексами; 2 - террейны, сложенные преимущественно средне- и позднепалеозойскими метаосадочными и метавулканическими комплексами; 3 - террейны, сложенные преимущественно позднепалеозойскими метаосадочными и метавулканическими комплексами; 4 - террейны, сложенные преимущественно раннемезозойскими турбидитовыми комплексами; 5 - позднеюрскораннемеловые конгломераты, гравелиты, песчаники; 6 - кайнозойские рыхлые отложения; 7 - разломы; 8 - геологические образования южной окраины Северо-Азиатского кратона; 9 - геологические образования северной окраины Амурского супертеррейна. Буквами обозначены террейны: GL - Галамский, DZ - Джагдинский, LN - Ланский, SK - Селемджино-Кербинский, TK - Тукурингрский, TR - Токурский, UL - Ульбанский, UB - Унья-Бомский, YK - Янканский, NL - Ниланский. На врезке звездочкой показан район исследований. Серая область - Монголо-Охотский складчатый пояс.

Fig. 1. Structural zoning of the eastern part of the Mongol-Okhotsk fold belt (after [Sorokin, 2001]).

1 - terranes composed mainly of the Early and Middle Paleozoic metasedimentary and metavolcanic formations; 2 - terranes composed mainly of the Middle and Late Paleozoic metasedimentary and metavolcanic formations; 3 - terranes composed mainly of the Late Paleozoic metasedimentary and metavolcanic formations; 4 - terranes composed mainly of the Early Mesozoic turbidite formations; 5 - Late Jurassic - Early Cretaceous conglomerates, gravelites and sandstones; 6 - loose Cenozoic deposits; 7 - faults; 8 - geological formations of the southern margin of the North Asian craton; 9 - geological formations of the northern margin of the Amur superterrane. The terranes are marked with letters: GL - Galam, DZ - Dzhagda, LN - Lan, SK - Selemdzha-Kerbi, TK - Tukuringra, TR - Tokur, UL - Ulban , UB - Un'yaBom, YK - Yankan, NL - Nilan. Asterisk in the inset - study area. Grey - Mongol-Okhotsk fold belt.

\section{4. РЕЗУЛЬТАТЫ U-Pb ГЕОХРОНОЛОГИЧЕСКИХ ИССЛЕДОВАНИЙ}

Геохронологические U-Th-Pb исследования выполнены для детритовых цирконов из стратиграфических подразделений Унья-Бомского террейна, а именно метаалевролитов амканской свиты (обр. C-1296), метаалевролитов курнальской свиты (обр. C-1290), метаалевролитов нелской свиты (обр. V-41). Места отбора образцов для геохронологических исследований показаны на рисунке 2.

Для U-Th-Pb геохронологических исследований из метаалевролитов нелской свиты (обр. V-41) было проанализировано 120 зерен детритовых цир- конов, для 83 из которых получены конкордантные оценки возраста. Большая часть цирконов имеют мезозойский и палеозойский возраст - пики на кривой относительной вероятности соответствуют значениям $\sim 222,345,399,432$ млн лет (рис. $3, a$ ). В значительном количестве присутствуют также палеопротерозойские и архейские цирконы (пики 1.9 и 2.5 млрд лет), а также несколько нео- и мезопротерозойских цирконов, не образующих статистически значимой выборки. Наиболее молодое зерно

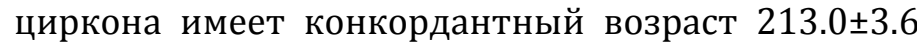
млн лет.

В ходе U-Th-Pb геохронологических исследований метаалевролита курнальской свиты (обр. 


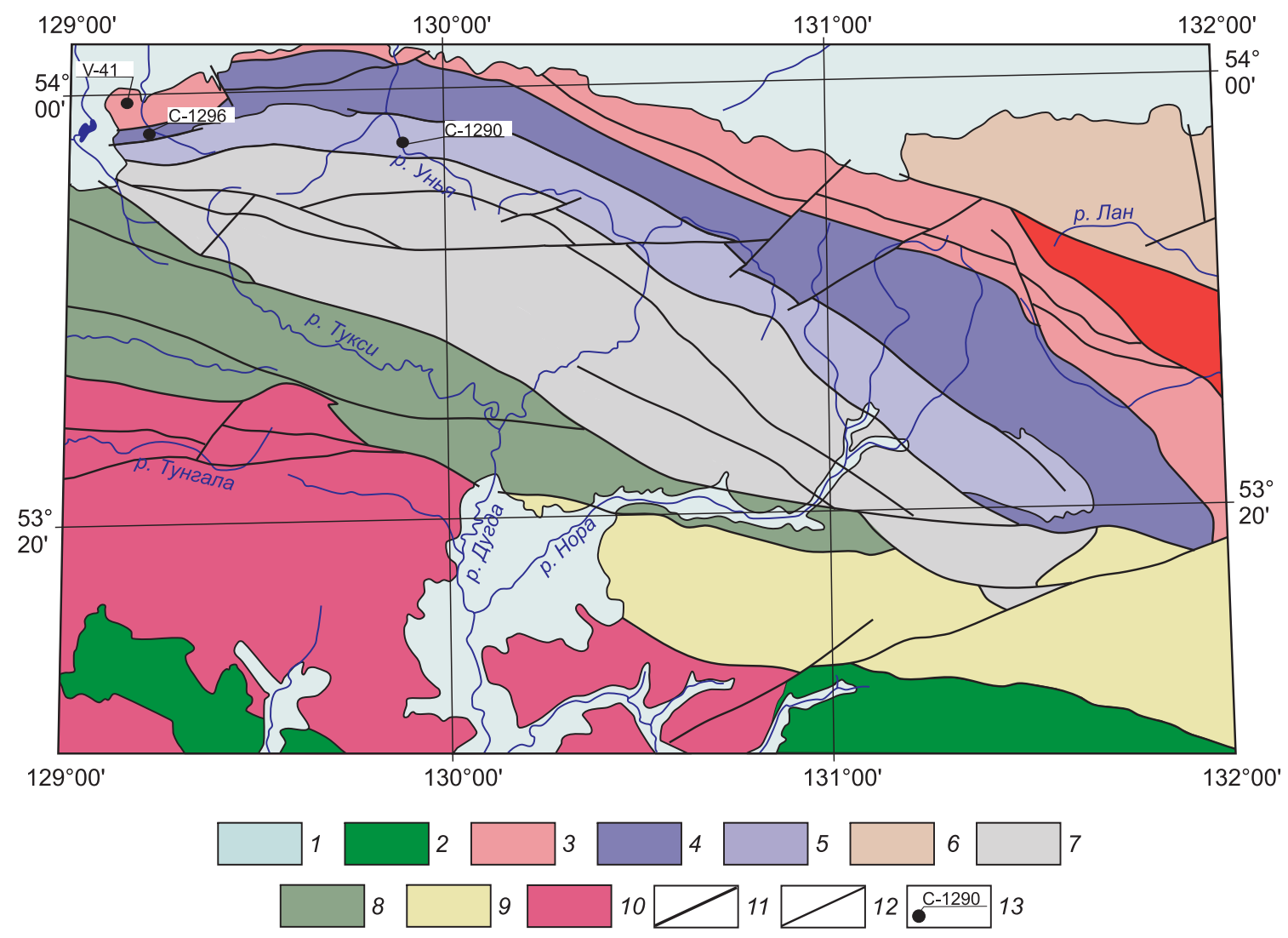

Рис. 2. Геологическая схема восточной части Монголо-Охотского складчатого пояса (по [Serezhnikov, Volkova, 2007], с изменениями авторов).

1 - кайнозойские рыхлые отложения; 2 - раннемеловые вулканиты среднего состава; 3-5 - раннемезозойские метатерригенные и метавулканогенные комплексы Унья-Бомского террейна: 3 - условно позднетриасовые нерасчлененные метаосадочные породы муяканской и нелской свит, 4 - условно раннеюрские метаосадочные породы курнальской свиты, 5 - условно среднеюрские метаосадочные породы амканской свиты; 6 - каменноугольные и пермские метатерригенные и метавулканогенные комплексы Ланского террейна; 7 - позднепалеозойские метатерригенные и метавулканогенные комплексы Джагдинского террейна; 8 - условно силурийские, девонские терригенные и вулканогенные комплексы Долбырь-Тунгалинского террейна; 9 - условно каменноугольные терригенные и вулканогенные комплексы Селемджино-Кербинского террейна; 10 - палеозойские интрузивные и осадочные комплексы северной окраины Амурского супертеррейна; 11 - главные разломы (границы между террейнами); 12 - второстепенные разломы; 13 - места отбора образцов для U-Th-Pb геохронологических исследований и их номера.

Fig. 2. Geological scheme of the eastern part of the Mongol-Okhotsk fold belt (modified after [Serezhnikov, Volkova, 2007).

1 - loose Cenozoic deposits; 2 - Early Cretaceous volcanics of medium composition; 3-5 - Early Mesozoic metaterrigenous and metavolcanogenic formations of the Un'ya-Bom terrane: 3 - conditionally Late Triassic undifferentiated metasedimentary rocks of the Muyakan and Nel formations, 4 - conditionally Early Jurassic metasedimentary rocks of the Kurnal formation, 5 - conditionally Middle Jurassic metasedimentary rocks of the Amkan formation; 6 - Carboniferous and Permian metaterrigenous and metavolcanogenic formations of the Lana terrane; 7 - Late Paleozoic metaterrigenous and metavolcanogenic formations of the Dzhagda terrane; 8 - conditionally Silurian and Devonian terrigenous and volcanogenic formations of the Dolbyr-Tungalin terrane; 9 - conditionally Carboniferous terrigenous and volcanogenic formations of the Selemdzha-Kerbi terrane; 10 - Paleozoic intrusive and sedimentary complexes of the northern margin of the Amur superterrane; 11 - main faults (boundaries between terranes); 12 - secondary faults; 13 - sampling sites for U-Th-Pb geochronological studies and corresponding site numbers.

C-1296) проанализированы 127 зерен детритовых цирконов, для 100 получены конкордантные оценки возраста. Большинство цирконов имеют мезозойский и палеозойский возраст (пики на кривой относительной вероятности соответствуют значениям 207, 245, 323, 362, 433, 473 млн лет). Два зерна циркона имеют неопротерозойский возраст 606 и 828 млн лет. Кроме того, для трех зерен циркона получены палеопротерозойские оценки воз- раста (по отношению ${ }^{207} \mathrm{~Pb} /{ }^{206} \mathrm{~Pb}$ ) в интервале 1735-1928 млн лет (рис. 3, б). Наиболее молодое зерно циркона имеет конкордантный возраст 194.0 \pm 4.4 млн лет.

Для U-Th-Pb геохронологических исследований метаалевролита амканской свиты (обр. С-1290) использованы 123 зерна детритовых цирконов, для которых получены 96 преимущественно мезозойских и палеозойских конкордантных оценок воз- 

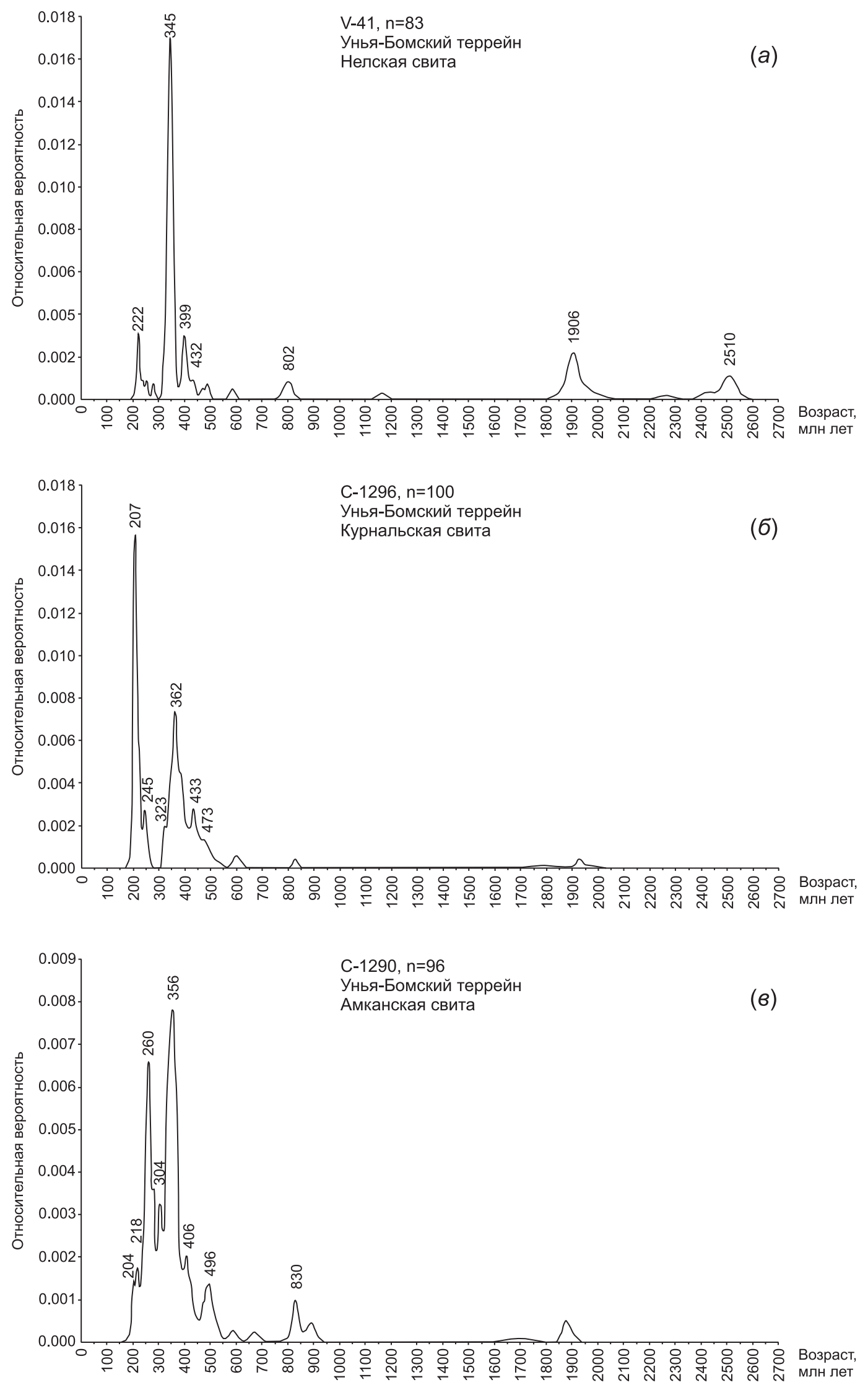

Рис. 3. Кривые относительной вероятности возрастов детритовых цирконов из: (a) - метаалевролита нелской свиты (обр. V-41); (б) - метаалевролита курнальской свиты (обр. С-1296); (в) - метаалевролита амканской свиты (обр. C-1290).

Fig. 3. Relative probability of detrital zircon ages: (a) - metasiltstone of the Nel formation (sample V-41); (б) - metasiltstone of the Kurnal formation (sample C-1296.); ( 8 ) - metasiltstone of the Amkan formation (sample C-1290). 
(a)

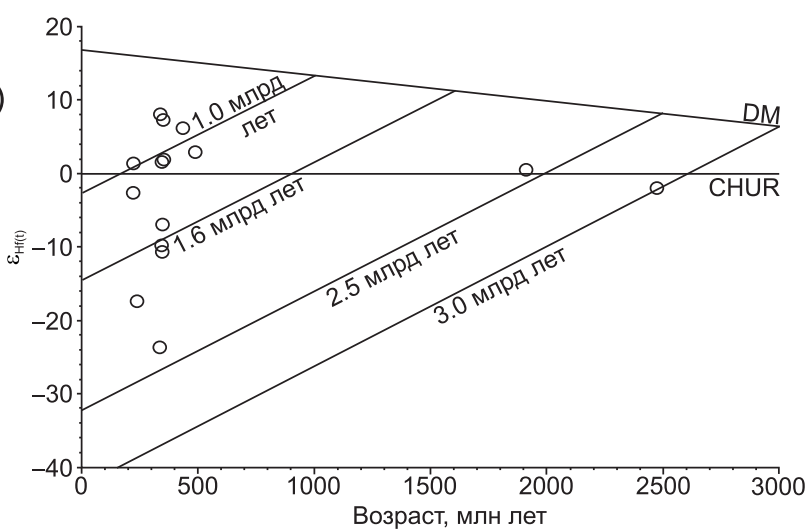

(б)

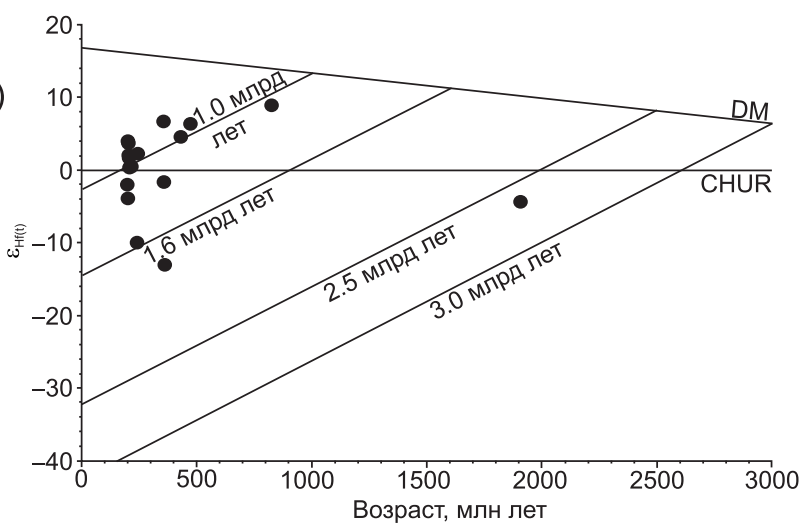

(в)

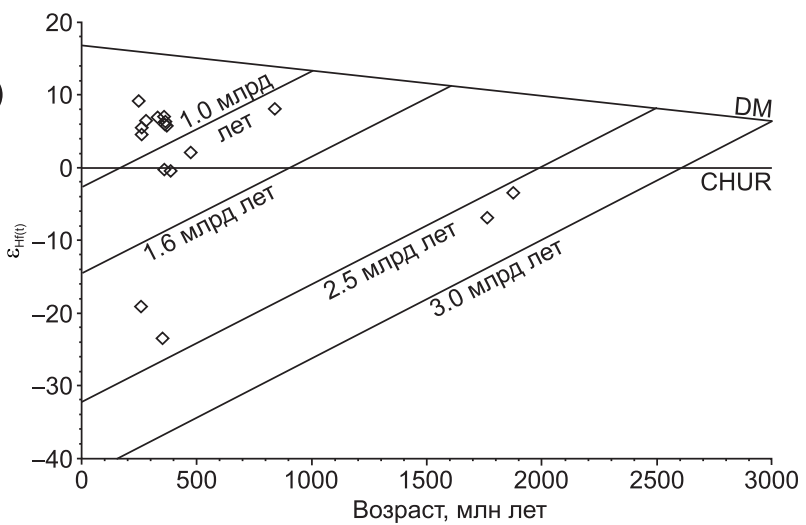

раста. Главные пики на кривой относительной вероятности возраста детритовых цирконов соответствуют 204, 218, 260, 278, 304, 356, 406, 496 млн лет (рис. 3, в). Присутствуют также шесть неопротерозойских цирконов, три из которых отвечают пику 830 млн лет и, кроме того, три зерна с палеопротерозойским возрастом. Наиболее молодое зерно

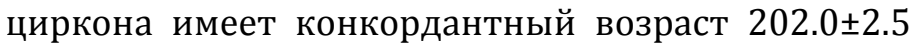
млн лет.

\section{5. РЕЗУЛЬТАТЫ LU-Hf ИЗОТОПНЫХ ИССЛЕДОВАНИЙ}

Lu-Hf изотопные исследования выполнены для цирконов в тех же точках, что и U-Th-Pb исследования. Всего анализировалось 15-17 зерен из каждого образца, при этом выбирались точки, для кото-
Рис. 4. Диаграмма $\varepsilon_{\mathrm{Hf}(\mathrm{t})}$ - возраст (млн лет) для цирконов из метаосадочных пород Унья-Бомского террейна: (a) - метаалевролита нелской свиты (обр. V-41); (б) метаалевролита курнальской свиты (обр. С-1296); (в) - метаалевролита амканской свиты (обр.С-1290). DM - деплетированная мантия, CHUR - однородный хондритовый резервуар.

Fig. 4. Diagram $\varepsilon_{\mathrm{Hf}(\mathrm{t})}$ - ages (Ma) of zircons from the metasedimentary rocks of the Un'ya-Bom terrane: $(a)$ - metasiltstone of the Nel formation (sample V-41); (б) - metasiltstone of the Kurnal formation (sample C-1296); (в) - metasiltstoneof the Amkan formation (sample C-1290). DM - depleted mantle; CHUR - homogeneous chondritic reservoir. рых получены конкордантные значения возраста. Результаты исследований приведены на рисунке 4 и в таблице.

Доминирующие мезозойские и палеозойские цирконы из метаалевролита нелской свиты (обр. V-41) характеризуются широкой вариативностью значений $\varepsilon_{\mathrm{Hf}(\mathrm{t})}$ и модельных возрастов $\mathrm{t}_{\mathrm{Hf(DM)}}, \mathrm{t}_{\mathrm{Hf}(\mathrm{C})}$. В первом приближении среди них можно выделить две группы. Цирконам первой группы свойственны положительные или слабоотрицательные значения $\varepsilon_{\mathrm{Hf}(\mathrm{t})}-$ от -2.6 до +8.1 и модельные возрасты не древнее конца мезопротерозоя $-\mathrm{t}_{\mathrm{Hf}(\mathrm{DM})}=1.0-0.6$ млрд лет, $\mathrm{t}_{\mathrm{Hf}(\mathrm{C})}=1.2-0.7$. Цирконы второй группы характеризуются отрицательными величинами $\varepsilon_{\mathrm{Hf}(\mathrm{t})}-$ от -6.9 до -23.6 и мезопалеопротерозойскими модельными возрастами $\mathrm{t}_{\mathrm{Hf}(\mathrm{DM})}=1.9-1.2$ млрд лет, $\mathrm{t}_{\mathrm{Hf(C)}}=2.3-1.5$ млрд лет (рис. 4, $a$, таблица). Палеопротерозойские и 


\section{Результаты Lu-Hf изотопных исследований цирконов из метаосадочных пород Унья-Бомского террейна}

Results of Lu-Hf isotope studies of zircons from the metasedimentary rocks of the Un'ya-Bom terrain

\begin{tabular}{llllll}
\hline № п/п $\quad$ № обр./№ зерна & $\begin{array}{l}\text { Возраст, } \\
\text { млн лет }\end{array}$ & $\left({ }^{176} \mathrm{Yb}+{ }^{176} \mathrm{Lu}\right) / 176 \mathrm{Hf}(\%)$ & $176 \mathrm{Lu} /{ }^{177} \mathrm{Hf}$ & $176 \mathrm{Hf} /{ }^{177} \mathrm{Hf}$ & $\pm(1 \mathrm{~s})$
\end{tabular}

Метаалевролиты нелской свиты

$\begin{array}{llll}1 & \mathrm{~V}-41 / 18 & 222.1 & 29.4 \\ 2 & \mathrm{~V}-41 / 92 & 223.4 & 60.9 \\ 3 & \mathrm{~V}-41 / 76 & 238.8 & 18.6 \\ 4 & \mathrm{~V}-41 / 103 & 336.2 & 12.5 \\ 5 & \mathrm{~V}-41 / 102 & 338.8 & 18.1 \\ 6 & \mathrm{~V}-41 / 101 & 344.3 & 11.3 \\ 7 & \mathrm{~V}-41 / 26 & 345.6 & 28.2 \\ 8 & \mathrm{~V}-41 / 107 & 347.1 & 18.5 \\ 9 & \mathrm{~V}-41 / 105 & 348.3 & 14.2 \\ 10 & \mathrm{~V}-41 / 128 & 351.2 & 12.0 \\ 11 & \mathrm{~V}-41 / 24 & 354 & 29.3 \\ 12 & \mathrm{~V}-41 / 36 & 435.7 & 34.0 \\ 13 & \mathrm{~V}-41 / 46 & 488.8 & 25.8 \\ 14 & \mathrm{~V}-41 / 65 & 1909 & 8.1 \\ 15 & \mathrm{~V}-41 / 87 & 2497.4 & 11.8\end{array}$

Метаалевролиты курнальской свиты

$\begin{array}{llll}16 & \mathrm{C}-1296 / 36 & 200.6 & 32.7 \\ 17 & \mathrm{C}-1296 / 78 & 203.2 & 26.0 \\ 18 & \mathrm{C}-1296 / 75 & 203.3 & 36.7 \\ 19 & \mathrm{C}-1296 / 84 & 205.5 & 23.3 \\ 20 & \mathrm{C}-1296 / 121 & 206.9 & 20.5 \\ 21 & \mathrm{C}-1296 / 40 & 208.4 & 13.4 \\ 22 & \mathrm{C}-1296 / 130 & 210.1 & 12.5 \\ 23 & \mathrm{C}-1296 / 29 & 218.7 & 17.5 \\ 24 & \mathrm{C}-1296 / 14 & 242.9 & 62.6 \\ 25 & \mathrm{C}-1296 / 86 & 246.4 & 31.1 \\ 26 & \mathrm{C}-1296 / 17 & 359.7 & 22.7 \\ 27 & \mathrm{C}-1296 / 9 & 363.4 & 28.6 \\ 28 & \mathrm{C}-1296 / 100 & 358 & 25.0 \\ 29 & \mathrm{C}-1296 / 71 & 433 & 33.0 \\ 30 & \mathrm{C}-1296 / 22 & 475.1 & 20.3 \\ 31 & \mathrm{C}-1296 / 77 & 827.3 & 18.2 \\ 32 & \mathrm{C}-1296 / 128 & 1908.6 & 10.0\end{array}$

Метаалевролиты амканской свиты

$\begin{array}{llll}33 & \mathrm{C}-1290 / 37 & 247.7 & 14.4 \\ 34 & \mathrm{C}-1290 / 16 & 257.7 & 35.1 \\ 35 & \mathrm{C}-1290 / 4 & 260.4 & 27.2 \\ 36 & \mathrm{C}-1290 / 122 & 260.9 & 22.5 \\ 37 & \mathrm{C}-1290 / 77 & 279.5 & 61.7 \\ 38 & \mathrm{C}-1290 / 50 & 329.8 & 23.9 \\ 39 & \mathrm{C}-1290 / 51 & 351.2 & 36.6 \\ 40 & \mathrm{C}-1290 / 59 & 357.6 & 13.6 \\ 41 & \mathrm{C}-1290 / 36 & 358.8 & 15.7 \\ 42 & \mathrm{C}-1290 / 7 & 361.3 & 33.6 \\ 43 & \mathrm{C}-1290 / 124 & 369.5 & 41.6 \\ 44 & \mathrm{C}-1290 / 119 & 363.4 & 26.2 \\ 45 & \mathrm{C}-1290 / 66 & 386.3 & 23.5 \\ 46 & \mathrm{C}-1290 / 23 & 473.3 & 13.2 \\ 47 & \mathrm{C}-1290 / 42 & 838.4 & 16.4 \\ 48 & \mathrm{C}-1290 / 6 & 1760.3 & 8.7 \\ 49 & \mathrm{C}-1290 / 15 & 1873.3 & 20.9\end{array}$

0.001791
0.003393
0.001143
0.000852
0.001197
0.000655
0.001742
0.001174
0.000806
0.000780
0.001908
0.001991
0.001726
0.000486
0.000719

\subsection{8 \\ 0.282687 \\ 0.282139 \\ 0.281902 \\ 0.282797 \\ 0.282287 \\ 0.282613 \\ 0.282264 \\ 0.282366 \\ 0.282765 \\ 0.282619 \\ 0.282692 \\ 0.282566 \\ 0.281600 \\ 0.281153}

0.001881

0.001619

0.002116

0.001483

0.001313

0.000856

0.000817

0.001137

0.003485

0.002298

0.001320

0.001865

0.001627

0.002181

0.001248

0.001276

0.000582

\subsection{8 \\ 0.282542 \\ 0.282767 \\ 0.282755 \\ 0.282707 \\ 0.282693 \\ 0.282655 \\ 0.282655 \\ 0.282356 \\ 0.282694 \\ 0.282511 \\ 0.282191 \\ 0.282750 \\ 0.282650 \\ 0.282667 \\ 0.282527 \\ 0.281466}

0.000825
0.002144
0.001680
0.001423
0.003657
0.001523
0.002381
0.000693
0.001063
0.002048
0.002483
0.001616
0.001515
0.000775
0.000940
0.000519
0.001203

$\begin{array}{llll}0.000015 & -2.6 & 1.0 & 1.2 \\ 0.000022 & 1.4 & 0.9 & 1.0 \\ 0.000026 & -17.3 & 1.6 & 1.9 \\ 0.000017 & -23.6 & 1.9 & 2.3 \\ 0.000025 & 8.1 & 0.6 & 0.7 \\ 0.000017 & -9.7 & 1.3 & 1.6 \\ 0.000016 & 1.6 & 0.9 & 1.1 \\ 0.000018 & -10.6 & 1.4 & 1.7 \\ 0.000018 & -6.9 & 1.2 & 1.5 \\ 0.000013 & 7.3 & 0.7 & 0.8 \\ 0.000021 & 1.9 & 0.9 & 1.1 \\ 0.000021 & 6.2 & 0.8 & 0.9 \\ 0.000028 & 2.9 & 1.0 & 1.1 \\ 0.000033 & 0.5 & 2.3 & 2.3 \\ 0.000019 & -2.4 & 2.9 & 3.0\end{array}$

0.000024 0.000019

0.000021

0.000018

0.000018

0.000021

0.000020

0.000026

0.000028

0.000019

0.000021

0.000019

0.000020

0.000016

0.000022

0.000017

0.000018

$-2.0$

$-3.9$

0.9

1.0

4.0

3.7

2.1

1.7

0.4

0.5

$-10.0$

2.3

$-1.6$

$-13.0$

6.7

4.6

6.4

8.9

$-4.3$
1.2

1.0

9

0.7

1.6

1.1

0.8

1.1

0.9

2.3

3.0

\section{1}

1.2

0.8

0.8

0.9

1.0

1.0

1.0

1.0

1.2

1.8

0.8

1.0

0.9

1.1

2.6
0.000022

0.000020

0.000027

0.000030

0.000030

0.000014

0.000026

0.000025

0.000020

0.000023

0.000028

0.000021

0.000020

0.000022

0.000026

0.000025

0.000020
9.2

$$
-19.1
$$

4.6

5.5

6.5

$$
6.9
$$

$-23.4$

7.0

$-0.2$

6.0

5.8

6.3

$-0.4$

2.1

8.1

$-6.9$

$-3.4$

П р и м е ч а н и е. Величины ошибок $(1 \sigma)$ определения отношения ${ }^{176} \mathrm{Hf} /{ }^{177} \mathrm{Hf}$ соответствуют последним значащим цифрам после запятой.

$\mathrm{N}$ o t e. In estimations of the ${ }^{176} \mathrm{Hf} /{ }^{177} \mathrm{Hf}$ ratios, error values $(1 \sigma)$ correspond to the last significant digits after the decimal point. 
неоархейские цирконы при близнулевых значениях $\varepsilon_{\mathrm{Hf}(\mathrm{t})}=-2.4 \ldots+0.5$ имеют модельные возрасты, превышающие 2.3 млрд лет.

Мезозойские и палеозойские цирконы из метаалевролита курнальской свиты (обр. С-1296) по величинам Lu-Hf изотопных параметров также могут быть разделены на две группы, подобные таковым в вышеописанном метаалевролите нелской свиты. При этом цирконы первой группы с положительными или слабоотрицательными значениями $\varepsilon_{\mathrm{Hf}(\mathrm{t})}$ - от -3.9 до +6.7 - и модельным возрастом не древнее конца мезопротерозоя $-t_{\mathrm{Hf}(\mathrm{DM})}=1.1-0.7$ млрд лет, $\mathrm{t}_{\mathrm{Hf}(\mathrm{c})}=1.2-0.8$ млрд лет существенно превалируют над цирконами второй группы с отрицательными величинами $\varepsilon_{\mathrm{Hf}(\mathrm{t})}-$ от -10.0 до -13.0 - и мезо- и палеопротерозойскими модельными возрастами $\mathrm{t}_{\mathrm{Hf}(\mathrm{DM})}=1.5-1.4$ млрд лет, $\mathrm{t}_{\mathrm{Hf}(\mathrm{C})}=1.8-1.6$ млрд лет (рис. 4,6, таблица). Зерно неопротерозойского циркона характеризуется положительным (+8.9) значением $\varepsilon_{\mathrm{Hf}(\mathrm{t})}$ и неопротерозойскими модельными возрастами $\mathrm{t}_{\mathrm{Hf}(\mathrm{DM})}=1.0$ млрд лет, $\mathrm{t}_{\mathrm{Hf}(\mathrm{C})}=1.1$ млрд лет. Наконец, единственному зерну палеопротерозойского циркона свойственны слабоотрицательная величина $\varepsilon_{\mathrm{Hf}(\mathrm{t})}=-4.3$ и неоархейские значения модельных возрастов $\mathrm{t}_{\mathrm{Hf}(\mathrm{DM})}=2.5$ млрд лет, $\mathrm{t}_{\mathrm{Hf}(\mathrm{C})}=2.6$ млрд лет.

Подобная закономерность также свойственна цирконам из метаалевролита амканской свиты (обр. С-1290). В частности, доминирующими являются мезозойские и палеозойские цирконы с положительными или слабоотрицательными значениями $\varepsilon_{\mathrm{Hf}(\mathrm{t})}-$ от -2.0 до +9.2 и модельными возрастами не древнее конца мезопротерозоя $-\mathrm{t}_{\mathrm{Hf}(\mathrm{DM})}=1.0-0.5$ млрд лет, $\mathrm{t}_{\mathrm{Hf}(\mathrm{C})}=1.2-0.6$ млрд лет (рис. 4, в, таблица). И лишь одно зерно (C-1290/51) имеет отрицательное значение $\varepsilon_{\mathrm{Hf}(\mathrm{t})}=-23.4$ и палеопротерозойский модельный возраст $\mathrm{t}_{\mathrm{Hf}(\mathrm{DM})}=2.0$ млрд лет, $\mathrm{t}_{\mathrm{Hf}(\mathrm{C})}=2.3$ млрд лет. Зерно неопротерозойского циркона характеризуется положительным (+8.1) значением $\varepsilon_{\mathrm{Hf}(\mathrm{t})}$ и неопротерозойским модельным возрастом $\mathrm{t}_{\mathrm{Hf}(\mathrm{DM})}=\mathrm{t}_{\mathrm{Hf}(\mathrm{C})}=$ $=1.1$ млрд лет. Зерну палеопротерозойского циркона свойственны слабоотрицательная величина $\varepsilon_{\mathrm{Hf}(\mathrm{t})}=$ $=-3.4$ и неоархейские значения модельных возрастов $\mathrm{t}_{\mathrm{Hf}(\mathrm{DM})}=2.4$ млрд лет, $\mathrm{t}_{\mathrm{Hf}(\mathrm{C})}=2.5$ млрд лет.

\section{6. ОБСУЖДЕНИЕ РЕЗУЛЬТАТОВ}

В результате проведенных геохронологических исследований установлено, что наиболее молодая популяция цирконов в метаалевролите нелской свиты (обр. V-41) имеет средний возраст 222 млн лет (см. рис. 3, a), а конкордантный возраст наиболее молодого циркона составляет $213 \pm 3.6$ млн лет. Эти данные не противоречат существующим представлениям [Serezhnikov, Volkova, 2007] о позднетриасовом возрасте этой свиты.
Для метаалевролита курнальской свиты (обр. C-1296) показано, что наиболее молодая популяция цирконов имеет средний возраст 207 млн лет, а конкордантный возраст наиболее молодого циркона составляет $194 \pm 4.4$ млн лет. Это также согласуется с раннеюрским возрастом свиты на основе фаунистических определений [Serezhnikov, Volkova, 2007].

Близкие (в пределах погрешности анализа) данные получены для метаалевролита амканской свиты (обр. С-129): возраст наиболее молодой популяции цирконов составляет 204 млн лет, а конкордантный возраст наиболее молодого циркона $202 \pm 2.5$ млн лет. С учетом отсутствия фауны в амканской свите нельзя исключать того, что курнальская и амканская свиты имеют один и тот же (раннеюрский) возраст. В любом случае взаимоотношение этих свит требует уточнения.

Полученные данные в совокупности с ранее проведенными исследованиями Тукурингрского террейна [Zaika et al., 2018b] указывают на то, что раннемезозойские осадочные комплексы в строении восточной части Монголо-Охотского пояса развиты существенно шире, чем принято считать в настоящее время.

Далее перейдем к обсуждению вопроса об источниках цирконов в исследованных отложениях. Однако перед этим следует напомнить, что восточная часть Монголо-Охотского пояса граничит с юго-восточным обрамлением Северо-Азиатского кратона с одной стороны и Амурским супертеррейном (композитным массивом) - с другой (см. рис. 1). В этой связи указанные структуры являются потенциальными источниками обломочного материала для осадочных комплексов Монголо-Охотского пояса, но при этом они резко различаются по своему строению и изотопным характеристикам слагающих их пород.

Как было показано выше, среди обломочных цирконов нелской свиты в значительном количестве присутствуют палеопротерозойские и архейские цирконы (пики 1.9 и 2.5 млрд лет). С учетом особенностей строения региона в качестве единственно возможного источника этих цирконов мы можем рассматривать породы станового комплекса [Velikoslavinskii et al., 2011, 2017], а также неоархейские и палеопротерозойские интрузии [Velikoslavinskii et al., 2017; Buchko et al., 2006, 2008] южного обрамления Северо-Азиатского кратона. В отличие от нелской свиты, в породах курнальской и амканской свит раннедокембрийские цирконы представлены единичными зернами, и к интерпретации этого обстоятельства мы вернемся чуть позже.

Неопротерозойские и раннепалеозойские цирконы, присутствующие во всех исследованных образцах, характеризуются Нf-модельными возрас- 
V.A. Zaika, A.A. Sorokin: Ages and sources of detrital zircons from the Early Mesozoic metasedimentary rocks of the Un'ya-Bom terrane...

тами не древнее позднего мезопротерозоя (рис. 4, таблица). Это обстоятельство затрудняет поиск их источников в пределах южного обрамления Северо-Азиатского кратона, где разновозрастные геологические комплексы характеризуются, как правило, раннедокембрийскими Nd- и Hf- модельными возрастами [Velikoslavinskii et al., 2011, 2012, 2015, 2016a, 2016b; Kotov et al., 2016; Larin et al., 2018]. В этой связи более логично, на наш взгляд, предполагать поступление таких цирконов со стороны континентальных массивов, входящих в состав Амурского супертеррейна. Это не противоречит геологическим данным. Так, в строении последних выявлены гранитоиды неопротерозойского возраста, а раннепалеозойские интрузии слагают значительную часть этих массивов [Wu et al., 2011; Sun et al., 2013; Sorokin et al., 2017, 2019].

Как было показано выше, в породах нелской, курнальской и амканской свит доминируют позднепалеозойские и раннемезозойские цирконы. При этом цирконы представлены двумя группами, существенно различающимися по Lu-Hf изотопным параметрам. Напомним, что цирконам одной группы свойственны положительные или слабоотрицательные значения $\varepsilon_{\mathrm{Hf}(\mathrm{t})}$ и, как правило, неопротерозойские $\mathrm{Nd}$-модельные возрасты. Цирконы другой группы характеризуются глубокими отрицательными величинами $\varepsilon_{\mathrm{Hf}(\mathrm{t})}$ и преимущественно палеопротерозойскими модельными возрастами (рис. 4, таблица). Это указывает на то, что источники этих групп цирконов, по-видимому, должны иметь различную изотопную структуру; иными словами, эти источники должны быть различными.

Так, в качестве источников каменноугольных цирконов с возрастом 336-348 млн лет (обр. V-41), 〜363 млн лет (обр. С-1296), 351 млн лет (обр. C-1290) с преимущественно палеопротерозойскими Hf-модельными возрастами (рис. 4, таблица) можно рассматривать гранитоиды олекминского комплекса с возрастом 358 2 млн лет [Larin et al., 2015], $360 \pm 2$ млн лет [Velikoslavinskii et al., 2016a], а также вулканические породы с возрастом $358 \pm 2$ млн лет Амазаро-Гилюйской зоны [Velikoslavinskii et al., 2016a] южного обрамления Северо-Азиатского кратона.

Поступление цирконов с возрастом 239 млн лет (обр. V-41), 243 млн лет (обр. 1296) и палеопротерозойскими Нf-модельными возрастами (рис. 4, таблица), на наш взгляд, также можно связывать с разрушением соответствующих по возрасту магматических и метаморфических пород южного обрамления Северо-Азиатского кратона. В частности, близкий возраст имеют метариолиты

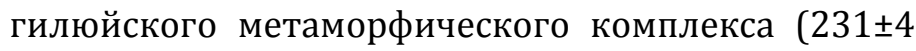
млн лет [Velikoslavinskii et al., 2016b]) и диориты, относимые к токско-алгоминскому комплексу (238 \pm 2 млн лет [Sal'nikova et al., 2006]).

Для цирконов с возрастом 222, 223, 339, 346, 351, 354 млн лет (обр. V-41), 200, 203, 206, 207, 208, 210, 219 246, 358, 360 млн лет (обр. С-1296) и практически всех цирконов в интервале 248-386 млн лет (обр. C-1290) с преимущественно неопротерозойскими Hf-модельными возрастами (таблица) следует рассматривать магматические или метаморфические породы, сформированные без существенного участия материала раннедокембрийской континентальной коры. В этой связи мы не можем предполагать, что поступление таких цирконов шло со стороны южного обрамления СевероАзиатского кратона.

В качестве альтернативной версии остается допустить, что источниками этих цирконов являются позднепалеозойские и раннемезозойские магматические комплексы северной окраины Амурского супертеррейна и (или) островные дуги, существовавшие внутри Монголо-Охотского океана. Такая интерпретация представляется вполне реальной, поскольку в строении континентальных массивов, входящих в Амурский супертеррейн, позднепалеозойские и раннемезозойские комплексы пользуются широким распространением [Sorokin et al., 2005, 2016; Wu et al., 2011; Sun et al., 2013; Wang et al., 2015; Tang et al., 2016]. Кроме того, эти породы характеризуются преимущественно неопротерозойскими Hf-модельными возрастами [Wang et al., 2015; Tang et al., 2016].

В целом, полученные данные указывают на то, что поступление материала в период накопления нелской, курнальской и амканской свит происходило из разных провинций, а именно - со стороны Амурского супертеррейна (с юга в современных координатах) и со стороны обрамления СевероАзиатского кратона (с севера в современных координатах). Однако незначительное количество в исследованных отложениях палеопротерозойских и архейских цирконов, а также палеозойских и мезозойских цирконов с раннедокембрийскими Hfмодельными возрастами свидетельствует о том, что вклад последнего источника был незначительным.

Кроме того, мы хотим обратить внимание на следующий важный момент. Исследованные нами нелская, курнальская и амканская свиты представляют собой не только предполагаемую [Serezhnikov, Volkova, 2007] стратиграфическую, но и, в определенной мере, латеральную (с севера на юг) осадочную последовательность в строении Унья-Бомского террейна. В этой связи достаточно закономерным представляется увеличение количества палеопротерозойских и архейских цирконов в нелской свите по сравнению с амканской и курнальской 
свитами, т.е. в северном направлении (по мере приближения к Северо-Азиатскому кратону). В этом же направлении увеличивается доля цирконов с древними модельными возрастами (рис. 4, таблица).

\section{7. ЗАКЛЮЧЕНИЕ}

В результате проведенных геохронологических исследований установлено, что конкордантный возраст наиболее молодого циркона в метаалевролите нелской свиты составляет 213 3.6 млн лет,

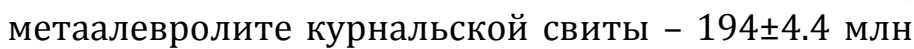

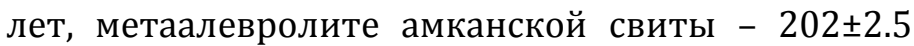
млн лет. С учетом полученных данных предполагаемый ранее среднеюрский возраст амканской свиты становится сомнительным. Скорее всего, курнальская и амканская свиты имеют один и тот же (раннеюрский) возраст. В любом случае взаимоотношение этих свит требует уточнения.

Полученные данные в совокупности с ранее проведенными исследованиями Тукурингрского террейна [Zaika et al., 2018b] указывают на то, что значительная часть осадочных комплексов восточной части Монголо-Охотского пояса имеет не палеозойский, как отражено на современных геологических картах, а раннемезозойский возраст.

Результаты U-Pb геохронологических, Lu-Hf изотопных исследований детритовых цирконов свидетельствуют о том, что снос материала в бассейн осадконакопления происходил преимущественно со стороны континентальных массивов Амурского супертеррейна (с юга в современных координатах).

\section{8. БЛАГОДАРНОСТИ}

Авторы благодарят сотрудников Института геологии и природопользования ДВО РАН Е.Н. Воропаеву, О.Г. Медведеву, а также персонал Центра LaserChron Университета штата Аризона (США) за проведение аналитических исследований. Геологические исследования выполнены в соответствии с планом НИР ИГиП ДВО РАН (тема АААА-А16116051810110-7), изотопно-геохимические и геохронологические исследования - при поддержке Российского научного фонда (проект 18-17-00002).

\section{9. ЛИТЕРАTУРА / REFERENCES}

Amelin Y., Lee D.C., Halliday A.N., Pidgeon R.T., 1999. Nature of the Earth's earliest crust from hafnium isotopes in single detrital zircons. Nature 399 (6733), 252-255. https://doi.org/10.1038/20426.

Black L.P., Kamo S.L., Allen C.M., Davis D.W., Aleinikoff J.N., Valley J.W., Mundil R., Campbell I.H., Korsch R.J., Williams I.S., Foudoulis $C$., 2004. Improved ${ }^{206} \mathrm{~Pb} /{ }^{238} \mathrm{U}$ microprobe geochronology by the monitoring of trace-element-related matrix effect; SHRIMP, ID-TIMS, ELA-ICP-MS and oxygen isotope documentation for a series of zircon standarts. Chemical Geology 205 (1-2), 115-140. https://doi.org/10.1016/j.chemgeo.2004.01.003.

Blichert-Toft J., Albarède F., 1997. The Lu-Hf isotope geochemistry of chondrites and the evolution of the mantle-crust system. Earth and Planetary Science Letters 148 (1-2), 243-258. https://doi.org/10.1016/S0012-821X(97)00040-X.

Buchko I.V., Sal'nikova E.B., Kotov A.B., Larin A.M., Velikoslavinskii S.D., Sorokin A.A., Sorokin A.P., Yakovleva S.Z., 2006. Paleoproterozoic gabbroanorthosites of the Selenga-Stanovoi Superterrane, southern framing of the Siberian Craton. Doklady Earth Sciences 407 (2), 372-375. https://doi.org/10.1134/S1028334X06030068.

Buchko I.V., Sorokin A.A., Sal'nikova E.B., Kotov A.B., Larin A.M., Sorokin A.P., Velikoslavinskii S.D., Yakovleva S.Z., 2008. Age and tectonic setting of the Kengurak-Sergachi gabbro-anorthosite massif (the Selenga-Stanovoi superterrane, southern frame of the Siberian craton). Stratigraphy and Geological Correlation 16 (4), 349-359. https://doi.org/ 10.1134/S0869593808040011.

Gehrels G.E., Valencia V., Ruiz J., 2008. Enhanced precision, accuracy, efficiency, and spatial resolution of U-Pb ages by laser ablation-multicollector-inductively coupled plasma-mass spectrometry. Geochemistry, Geophysics, Geosystems 9 (3), Q03017. https://doi.org/10.1029/2007GC001805.

Griffin W.L., Belousova E.A., Shee S.R., Pearson N.J., O'Reilly S.Y., 2004. Archean crustal evolution in the northern Yilgarn craton: U-Pb and Hf-isotope evidence from detrital zircons. Precambrian Research 131 (3-4), 231-282. https:// doi.org/10.1016/j.precamres.2003.12.011.

Khanchuk A.I., Didenko A.N., Popeko L.I., Sorokin A.A., Shevchenko B.F., 2015. Structure and evolution of the MongolOkhotsk orogenic belt. In: A. Kröner (Ed.), The Central Asian orogenic belt. Geology, evolution, tectonics, and models. Germany. Borntraeger Science Publishers, Stuttgart, p. 211-234.

Kotov A.B., Velikoslavinskii S.D., Kovach V.P., Sorokin A.A., Sorokin A.P., Skovitina T.M., Zagornaya N.Yu., Wang K.-L., Chung S.-L., Jahn B.-M., 2016. Paleoproterozoic age of the Zeya group, Stanovoy complex of the Dzhugdzhur-Stanovoy superterrane (Central Asian mobile belt): results of Sm-Nd isotopic and U-Th-Pb geochronological (LA-ICP-MS) analyses. Doklady Earth Sciences 471 (2), 1234-1237. https://doi.org/10.1134/S1028334X16120114.

Larin A.M., Kotov A.B., Kovach V.P., Sal'nikova E.B., Yarmolyuk V.V., Velikoslavinskii S.D., Yakovleva S.Z., Plotkina Yu.V., 2015. Granitoids of the Olekma Complex in the Selenga-Stanovoi superterrane of the Central Asian mobile belt: 
Age and tectonic position. Doklady Earth Sciences 464 (1), 903-906. https://doi.org/10.1134/S1028334X15090 093.

Larin A.M., Kotov A.B., Sal'nikova E.B., Kovach V.P., Ovchinnikova G.V., Savatenkov V.M., Velikoslavinskii S.D., Sorokin A.A., Vasil'eva I.M., Sergeeva N.A., Mel'nikov N.N., Wang K.-L., Chun S.-L., 2018. Granitoids of the Pozdnestanovoy complex of the Dzhugdzhur-Stanovoy superterrane, Central Asia fold belt: age, tectonic setting, and sources. Petrology 26 (5), 447-468. https://doi.org/10.1134/S0869591118050041.

Ludwig K.R., 2008. Isoplot 3.6. Berkeley Geochronology Center Special Publication, vol. 4, 77 p.

Mattinson J.M., 2010. Analysis of the relative decay constants of 235U and 238U by multi-step CA-TIMS measurements of closed-system natural zircon samples. Chemical Geology 275 (3-4), 186-198. https://doi.org/10.1016/j.chemgeo. 2010.05.007.

Natal'in B., 1993. History and modes of Mesozoic accretion in southeastern Russia. Island Arc 2 (1), 15-34. https:// doi.org/10.1111/j.1440-1738.1993.tb00072.x.

Paces J.B., Miller Jr. J.D., 1993. Precise U-Pb ages of Duluth complex and related mafic intrusions, northeastern Minnesota: Geochronological insights to physical, petrogenetic, paleomagnetic, and tectonomagmatic processes associated with the $1.1 \mathrm{Ga}$ midcontinent rift system. Journal of Geophysical Research: Solid Earth 98 (B8), 13997-14013. https://doi.org/10.1029/93JB01159.

Parfenov L.M., Popeko L.I., Tomurtogoo O., 2001. Problems of tectonics of the Mongol-Okhotsk orogenic belt. Geology of Pacific Ocean 16 (5), 797-830.

Sal'nikova E.B., Larin A.M., Kotov A.B., Glebovitsky V.A., Velikoslavinsky S.D., Sorokin A.A., Yakovleva S.Z., Fedoseenko A.M., Anisimova I.V., 2006. The Toksko-Algomin igneous complex of the Dzhugdzhur-Stanovoi folded region: age and geodynamic setting. Doklady Earth Sciences 409 (2), 888-892. https://doi.org/10.1134/S1028334X06060110.

Serezhnikov A.N., Volkova Yu.R., 2007. State Geological Map of the Russian Federation. Scale 1:1000000. Third Generation. Sheet N-52 (Zeya). Far East Series. Publishing House of A.P. Karpinsky Russian Geological Research Institute, Saint Petersburg (in Russian) [Сережников А.Н., Волкова Ю.Р. Государственная геологическая карта Российской Федерации. Масштаб 1:1000000. Третье поколение. Лист N-52 (Зея). Дальневосточная серия. СанктПетербург: Картографическая фабрика ВСЕГЕИ, 2007].

Sorokin A.A., 2001. Paleozoic accretionary complexes in the eastern segments of the Mongolia-Okhotsk foldbelt. Tikhookeanskaya Geologiya 20 (6), 31-36 (in Russian) [Сорокин А.А. Палеозойские аккреционные комплексы восточного сегмента Монголо-Охотского складчатого пояса // Тихоокеанская геология. 2001. Т. 20 . № 6. C. 31-36].

Sorokin A.A., Kotov A.B., Kudryashov N.M., Kovach V.P., 2005. Late Paleozoic Urusha magmatic complex in the southern framing of the Mongolia-Okhotsk belt (Amur Region): age and geodynamic setting. Petrology 13 (6), 596-610.

Sorokin A.A., Kotov A.B., Kudryashov N.M., Kovach V.P., 2016. Early Mesozoic granitoid and rhyolite magmatism of the Bureya Terrane of the Central Asian orogenic belt: Age and geodynamic setting. Lithos 261, 181-194. https://doi.org/10.1016/j.lithos.2016.03.008.

Sorokin A.A., Kudryashov N.M., Kotov A.B., Kovach V.P., 2017. Age and tectonic setting of the Early Paleozoic magmatism of the Mamyn Terrane, Central Asian orogenic belt, Russia. Journal of Asian Earth Sciences 144, 22-39. https:// doi.org/10.1016/j.jseaes.2017.01.017.

Sorokin A.A., Ovchinnikov R.O., Xu W.L., Kovach V.P., Yang H., Kotov A.B., Ponomarchuk V.A., Travin A.V., Plotkina Yu.V., 2019. Ages and nature of the protolith of the Tulovchikha metamorphic complex in the Bureya Massif, Central Asian orogenic belt, Russia: evidence from U-Th-Pb, Lu-Hf, Sm-Nd, and ${ }^{40} \mathrm{Ar} /{ }^{39} \mathrm{Ar}$ data. Lithos $332-333,340-354$. https://doi.org/10.1016/j.lithos.2019.03.001.

Söderlund U., Patchett P.J., Vervoort J.D., Isachsen C.E., 2004. The ${ }^{176} \mathrm{Lu}$ decay constant determined by Lu-Hf and U-Pb isotope systematics of Precambrian mafic intrusions. Earth and Planetary Science Letters 219 (3-4), 311-324. https://doi.org/10.1016/S0012-821X(04)00012-3.

Stacey J.S., Kramers I.D., 1975. Approximation of terrestrial lead isotope evolution by a two-stage model. Earth and Planet Science Letters 26 (2), 207-221. https://doi.org/10.1016/0012-821X(75)90088-6.

Sun D.Y., Gou J., Wang T.H., Ren Y.S., Liu Y.J., Guo H.Y., Liu X.M., Hu Z.C., 2013. Geochronological and geochemical constraints on the Erguna massif basement, NE China - subduction history of the Mongol-Okhotsk oceanic crust. International Geology Review 55 (14), 1801-1816. https://doi.org/10.1080/00206814.2013.804664.

Tang J., Xu W.L., Wang F., Zhao S., Wang W., 2016. Early Mesozoic southward subduction history of the MongolOkhotsk oceanic plate: Evidence from geochronology and geochemistry of Early Mesozoic intrusive rocks in the Erguna Massif, NE China. Gondwana Research 31, 218-240. https://doi.org/10.1016/j.gr.2014.12.010.

Velikoslavinskii S.D., Kotov A.B., Sal'nikova E.B., Larin A.M., Sorokin A.A., Sorokin A.P., Kovach V.P., Tolmacheva E.V., Gorokhovskii B.M., 2011. Age of the Ilikan Sequence from the Stanovoi Complex of the Dzhugdzhur-Stanovoi Superterrane, Central-Asian fold belt. Doklady Earth Sciences 438 (1). https://doi.org/10.1134/S1028334X11050400.

Velikoslavinskii S.D., Kotov A.B., Salnikova E.B., Larin A.M., Sorokin A.A., Sorokin A.P., Kovach V.P., Tolmacheva E.V., Yakovleva S.Z., Anisimova I.V., 2012. Age of the Ust'-Gilyui sequence in the Stanovoi Complex of the SelengaStanovoi Superterrain, Central Asian fold belt. Doklady Earth Sciences 444 (2), 661-665. https://doi.org/10.1134/ S1028334X12060086. 
Velikoslavinskii S.D., Kotov A.B., Kovach V.P., Sorokin A.A., Sorokin A.P., Tolmacheva E.V., Wang K.L., Cung S.L., 2015. The Paleoproterozoic age of protoliths of metasedimentary rocks of the Sutam formation of the Aldan granulite-gneiss megacomplex (Stanovoi suture). Doklady Earth Sciences 463 (2), 765-769. https://doi.org/10.1134/S1028334X 15080073.

Velikoslavinskii S.D., Kotov A.B., Kovach V.P., Tolmacheva E.V., Larin A.M., Sorokin A.A., Sorokin A.P., Wang K.L., Salnikova E.B., 2016a. Age, sources, and provenances of protoliths of metasedimentary rocks of the Dzheltulak group, Dzheltulak suture. Doklady Earth Sciences 468 (2), 545-548. https://doi.org/10.1134/S1028334X16060027.

Velikoslavinskii S.D., Kotov A.B., Kovach V.P., Larin A.M., Sorokin A.A., Sorokin A.P., Tolmacheva E.V., Salnikova E.B., Wang K.L., Jahn B.M., Cung S.L., 2016b. Mesozoic age of the Gilyui Metamorphic Complex in the junction zone of the Selenga-Stanovoi and Dzhugdzhur-Stanovoi superterranes, Central Asian fold belt. Doklady Earth Sciences 468 (2), 561-565. https://doi.org/10.1134/S1028334X16060167.

Velikoslavinskii S.D., Kotov A.B., Kovach V.P., Tolmacheva E.V., Sorokin A.A., Sal'nikova E.B., Larin A.M., Zagornaya N.Yu., Wang K.L., Chung S.-L., 2017. Age and tectonic position of the Stanovoi metamorphic complex in the eastern part of the Central Asian foldbelt. Geotectonics 51 (4), 341-352. https://doi.org/10.1134/S0016852117040070.

Vervoort J.D., Patchett P.J., 1996. Behavior of hafnium and neodymium isotopes in the crust: constraints from Precambrian crustally derived granites. Geochimica et Cosmochimica Acta 60 (19), 3717-3733. https://doi.org/10.1016/ 0016-7037(96)00201-3.

Wang W., Tang J., Xu W.L., Wang F., 2015. Geochronology and geochemistry of Early Jurassic volcanic rocks in the Erguna Massif, northeast China: Petrogenesis and implications for the tectonic evolution of the Mongol-Okhotsk suture belt. Lithos 218-219, 73-86. https://doi.org/10.1016/j.lithos.2015.01.012.

Wu F.Y., Sun D.Y., Ge W.C., 2011. Geochronology of the Phanerozoic granitoids in northeastern China. Journal of Asian Earth Sciences 41 (1), 1-30. https://doi.org/10.1016/j.jseaes.2010.11.014.

Zaika V.A., Sorokin A.A., Kovach V.P., 2018a. Sources and source areas of the Upper Paleozoic metasedimentary rocks of the Dzhagda terrane of the Mongol-Okhotsk fold belt: the results of Sm-Nd isotope geochemical studies. Geodynamics \& Tectonophysics 9 (4), 1331-1338 (in Russian) [Заика В.А., Сорокин А.А., Ковач В.П. Источники и области сноса верхнепалеозойских метаосадочных пород Джагдинского террейна Монголо-Охотского складчатого пояса: результаты Sm-Nd изотопно-геохимических исследований // Геодинамика и тектонофизика. 2018. Т. 9. № 4. С. 1331-1338]. https://doi.org/10.5800/GT-2018-9-4-0398.

Zaika V.A., Sorokin A.A., Xu B., Kotov A.B., Kovach V.P., 2018b. Geochemical features and sources of metasedimentary rocks of the western part of the Tukuringra terrane of the Mongol-Okhotsk fold belt. Stratigraphy and Geological Correlation 26 (2), 157-178. https://doi.org/10.1134/S0869593818020077.

Zaika V.A., Sorokin A.A., Kovach V.P., Sorokin A.P., Kotov A.B., 2019. Age and sources of Lower Mesozoic metasedimentary rocks of the Un'ya-Bom terrane in the Mongol-Okhotsk fold belt: results of U-Pb geochronological (LA-ICP-MS) and Sm-Nd isotope studies. Doklady Earth Sciences 484 (2), 115-119. https://doi.org/10.1134/ S1028334X19020089.

\section{CВЕДЕНИЯ ОБ АВTOPAX | INFORMATION ABOUT AUTHORS}

\section{Виктор Александрович Заика}

аспирант, м.н.с.

Институт геологии и природопользования ДВО РАН

675000, Благовещенск, пер. Рёлочный, 1, Россия

$\triangle$ e-mail: zaikava@ignm.ru

(iD) https://orcid.org/0000-0003-2842-0608

\section{Андрей Анатольевич Сорокин}

докт. геол.-мин. наук, директор, зав. лабораторией

Институт геологии и природопользования ДВО РАН

675000, Благовещенск, пер. Рёлочный, 1, Россия

e-mail: sorokin@ascnet.ru

(iD) https://orcid.org/0000-0002-8879-5412
Viktor A. Zaika

Post-Graduate Student, Junior Researcher

Institute of Geology and Natural Management, Far East Branch of RAS

1 Relochniy lane, Blagoveshchensk 675000, Russia

\section{Andrey A. Sorokin}

Doctor of Geology and Mineralogy, Director, Head of Laboratory

Institute of Geology and Natural Management, Far East Branch of RAS

1 Relochniy lane, Blagoveshchensk 675000, Russia 